\title{
ORIGINAL
}

\section{Effects of CBMIDA and Zn-DTPA in Drinking Water on Removal of Plutonium in Rats}

\author{
Satoshi FukudA, ${ }^{* * 1}$ Haruzo IIDA, ${ }^{* *, * 1}$ Yuyuan HseIH*2 \\ and Wenzhi CHEN $* 2$
}

(Received October 5, 1994)

(Accepted April 19, 1995)

\begin{abstract}
The effects of the oral administration of CBMIDA [catechol-3,6-bis(methyleiminodiacetic acid)], given in drinking water, on the removal of plutonium in rats were compared to those of Zn-DTPA. Male Wistar rats received a daily dose of $120 \mu \mathrm{mol} / \mathrm{kg}$ or $1,200 \mu \mathrm{mol} / \mathrm{kg}$ of CBMIDA or Zn-DTPA, given in drinking water, for 4 weeks after plutonium injection. The content of plutonium in bone, liver, kidney, spleen, and testis was measured by a liquid scintillation spectrometry after treatment of the organs by a wet ash method. The plutonium content of each organ in the $120 \mu \mathrm{mol} / \mathrm{kg}$ groups of CBMIDA and Zn-DTPA was not significantly reduced. The content of plutonium in the $1,200 \mu \mathrm{mol} / \mathrm{kg}$ groups of both CBMIDA and Zn-DTPA was, however, significantly reduced, to $65.7 \%(p<0.001)$ and $76.8 \%(p<0.05)$, respectively of the control in bone, and to $66.6 \%(p<0.05)$ and $44.0 \%(p<0.01)$, respectively, in liver. There were no significant decreases in kidney, spleen, and testis in the $1,200 \mu \mathrm{mol} / \mathrm{kg}$ dose CBMIDA group, but there were significant decreases in these organs in the $1,200 \mu \mathrm{mol} / \mathrm{kg}$ dose Zn-DTPA group. These results showed that, when given orally, CBMIDA was more effective in removing plutonium from bone than Zn-DTPA, a finding similar to the results were achieved with the intravenous injection of both agents in our previous study.
\end{abstract}

KEY WORDS: oral administration, CBMIDA, plutonium, Zn-DTPA, rat

\section{INTRODUCTION}

CBMIDA is a chelating agent that removes plutonium from bone, the target organ, more effectively than $\mathrm{Zn}-\mathrm{DTPA}^{1)}$; its side effects are similar to those of $\mathrm{Zn}-\mathrm{DTPA}^{2)}$ when injected intravenously. The selection of the route of administration for a chelating agent depends on the timing of the initial treatment and the duration of the chelation therapy. The oral administration of chelating agents is advantageous in that con-

* 福田 俊, ** 飯田治三

*1 放射線医学総合研究所内部被曝研究部; 千葉市稲毛区穴川 4-9-1 (T263)

Division of Comparative Radiotoxicology, National Institute of Radiological Sciences; 9-1, Anagawa 4-chome, Inage-ku, Chiba 263, Japan.

*2 Shanghai Institute of Materia Medica, Chinese Academy of Sciences; 319, Yuyang Road, Shanghai, 200031, China. taminated persons can take the agent immediately after exposure, and can continue the treatment without the pain and the inconvenience caused by repeated intraveous injections during protracted treatment..$^{3-9)}$ However, the disadvantage of the oral route is that the intestinal absorption rate is low. ${ }^{10-13)}$

The calcium and zinc salts of DTPA (diethylenetriaminepentaacetic acid) are, at present, the most effective chelating agents available for removing plutonium and other actinides from the human body. Zn-DTPA is very suitable for oral administration since its toxicity in the intestine is lower than that of Ca-DTPA; it is also more effective for the removal of plutonium than Ca-DTPA when given orally. ${ }^{14-18)}$

The present study was performed to clarify the effect of the oral administration of another chelating agent, CBMIDA, in drinking water in the 
Table 1 Plutonium content $(\mathrm{Bq} / \mathrm{g})$ in organs of each group.

\begin{tabular}{lccccc}
\hline \multicolumn{1}{c}{ Group } & Bone (Femur) & Liver & Kidney & Spleen & Testis \\
\hline Control & $133.8 \pm 20.5$ & $52.6 \pm 17.6$ & $48.4 \pm 14.8$ & $36.3 \pm 7.4$ & $5.1 \pm 1.0$ \\
CBMIDA $120 \mu \mathrm{mol} / \mathrm{kg}$ & $109.9 \pm 22.6$ & $50.3 \pm 15.4$ & $52.3 \pm 16.3$ & $37.2 \pm 12.1$ & $4.6 \pm 0.8$ \\
Zn-DTPA $120 \mu \mathrm{mol} / \mathrm{kg}$ & $117.0 \pm 17.8$ & $50.4 \pm 9.3$ & $43.2 \pm 6.6$ & $34.9 \pm 3.1$ & $4.7 \pm 0.7$ \\
CBMIDA $1,200 \mu \mathrm{mol} / \mathrm{kg}$ & $87.9 \pm 14.3^{* * *} 35.0 \pm 4.1^{*}$ & $57.8 \pm 11.0$ & $32.4 \pm 5.3$ & $4.5 \pm 1.0$ \\
Zn-DTPA $1,200 \mu \mathrm{mol} / \mathrm{kg}$ & $102.7 \pm 21.0^{*}$ & $23.1 \pm 3.1^{* *}$ & $23.9 \pm 5.8^{* *}$ & $28.1 \pm 3.0^{*}$ & $3.2 \pm 0.7^{* *}$ \\
\hline
\end{tabular}

Each value indicates the mean \pm standard deviation for five rats.

$*, * *, * * *$ Significant differences from the control ${ }^{*} p<0.05,{ }^{* *} p<0.01,{ }^{* * *} p<0.001$.

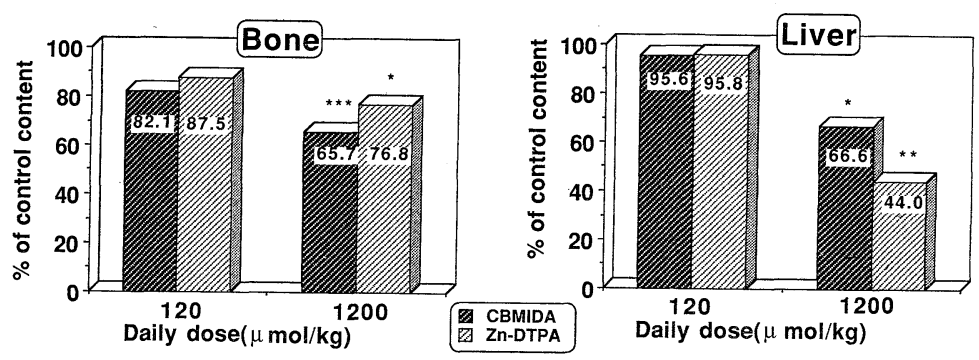

Fig. 1 Plutonium content of bone and liver as percentage of control in the $120 \mu \mathrm{mol} / \mathrm{kg}$ and $1,200 \mu \mathrm{mol} / \mathrm{kg}$ dose groups of CBMIDA and Zn-DTPA. $*, * *, * * *$ Significant differences from the control, ${ }^{*} p<0.05,{ }^{* *} p<0.01$, $* * * p<0.001$.

removal of plutonium in rats and to compare the effect to that of Zn-DTPA.

\section{MATERIALS AND METHODS}

Thirty male Wistar rats, 3 months of age, were injected intraveously with plutonium $\left(5.6 \times 10^{3} \mathrm{~Bq}\right.$ of ${ }^{239} \mathrm{Pu}$, in $0.12 \mathrm{ml}$ of $0.008 \mathrm{M}$ sodium citrate solution; $1.85 \times 10^{4} \mathrm{~Bq} / \mathrm{kg}$ body weight, $\mathrm{pH}$ adjusted to 7.2) after being anesthetized with a combination of ketamine hydrochloride and xylazine. We used an air-tight box for the administration of plutonium to small animals and wore gloves for the procedure. The plutonium-injected rats were divided into four treatment groups, each containing five animals; those receiving $120 \mu \mathrm{mol} /$ $\mathrm{kg}$ and $1,200 \mu \mathrm{mol} / \mathrm{kg}$ doses of CBMIDA, those receiving $120 \mu \mathrm{mol} / \mathrm{kg}$ and $1,200 \mu \mathrm{mol} / \mathrm{kg}$ doses of $\mathrm{Zn}$-DTPA, and a control group of ten animals.

The body weights of the animals were measured before and after the experiment. The concentration of chelating agents in the drinking water was $1.67 \mu \mathrm{mol} / \mathrm{ml}$ for the $120 \mu \mathrm{mol} / \mathrm{kg}$ dose groups and $15 \mu \mathrm{mol} / \mathrm{ml}$ for the $1,200 \mu \mathrm{mol} / \mathrm{kg}$ dose groups. The net doses, calculated from the mean daily intake of drinking water during the experiment, were $114 \mu \mathrm{mol} / \mathrm{kg}$ and $1,165 \mu \mathrm{mol} / \mathrm{kg}$ in the CBMIDA groups, and $120 \mu \mathrm{mol} / \mathrm{kg}$ and 1,237 $\mu \mathrm{mol} / \mathrm{kg}$ in the $\mathrm{Zn}$-DTPA groups.

The animals were sacrificed 4 weeks after the plutonium injection. The femur, liver, kidney, spleen, and testis were removed and weighed. The whole femur and a measured part (about 0.5 g) of other organs were each placed in a crucible and incinerated at $700^{\circ} \mathrm{C}$ for $24 \mathrm{~h}$. Two $\mathrm{ml}$ of a solution containing nitric acid: distilled water: hydrofluoric acid (150:100:0.9) was added the crucible and subsequently $1 \mathrm{ml}$ of the $2 \mathrm{ml}$ was pipetted into a counting vial. The alpha activity of plutonium in the vial was measured with an alpha liquid scintillation counter for $30 \mathrm{~min}$. Recovery and counting efficiency were confirmed by alpha spectrometry, using an electrodeposited sample made of the same plutonium source as that used in this method.

\section{RESULTS}

Table 1 shows the plutonium content $(\mathrm{Bq} / \mathrm{g})$ of the organs in each gorup. The plutonium 
content of bone and liver as a percentage of control, is shown in Fig. 1. In the CBMIDA and Zn-DTPA $120 \mu \mathrm{mol} / \mathrm{kg}$ dose groups, there were no significant reductions in values of any organs compared to control values. In both $1,200 \mu \mathrm{mol} /$ $\mathrm{kg}$ dose groups, the plutonium content of bone and liver was decreased significantly, the plutonium content in bone as a percentage of that in the control group being reduced significantly, to $65.7 \%$ $(p<0.001)$ in the CBMIDA group, and to $76.8 \%$ $(p<0.05)$ in the Zn-DTPA group. The content in liver was reduced significantly, to $66.6 \%$ of the control value $(p<0.05)$ in the CBMIDA group, and to $44.0 \%(p<0.01)$ in the Zn-DTPA group. There were also significant reductions in the kidney $(p<0.01)$, spleen $(p<0.05)$, and testis $(p<$ $0.01)$ in the Zn-DTPA group, but were no significant reductions in these organs in the CBMIDA group.

There were no significant differences in the body weight of rats before and after the experiment in any groups. During the experiment, no unusual clinical findings such as diarrhea and change in intake of drinking water were observed. The daily intake of water was similar in all groups. In the anatomical findings, very slight congestion of the small intestine was observed in the 1,200 $\mu \mathrm{mol} / \mathrm{kg} \mathrm{Zn}$-DTPA group.

\section{DISCUSSION}

The findings indicate that a high dose $(1,200$ $\mu \mathrm{mol} / \mathrm{kg}$ ) of CBMIDA and Zn-DTPA significantly reduced plutonium content in the body, whereas a low dose $(120 \mu \mathrm{mol} / \mathrm{kg})$ was not effective although it slightly reduced plutonium content in bone. These effects achieved by the oral administration of a high dose of the two chelating agents, however, are lower than those achieved with intravenous injections of daily doses of $150 \mu \mathrm{mol} / \mathrm{kg}$ of CBMIDA or of Zn-DTPA given for 2 weeks, in which plutonium content in the skeleton of rats was reduced to $18 \%$ and $42 \%$, respectively, of control values and plutonium content in the liver was reduced to $8 \%$ and $7 \%$, respectively, of control values. ${ }^{1)}$ The reduced efficacy of the oral route was due to mainly the low intestinal absorption rates of these chelating agents. The absorption rate of $\mathrm{Zn}-\mathrm{DTPA}$ is $3-8 \%^{9-13)}$ and that of CBMIDA may be similar. As there are almost no differences in the absorption rates of chelating agents through the small intestine among rats, dogs and humans, it would be reasonable to extrapolate the findings in this experiment to humans.

In this experiment, the initial timing of the intake of chelating agents was delayed, since it took a few hours for the animals to recover from the anesthesia, whereas the plutonium was injected intravenously and deposited in organs such as bone and liver with in a short time. A sufficient concentration of chelating agent in the blood during the residence of plutonium in blood would thus not have been obtained from the drinking water. If these chelating agents were to be orally administered to rats that had inhaled plutonium and, moreover, if they were administered for a long term, greater efficacy could be expected, since plutonium translates slowly from lung to blood; however, the administration of chelating agents should be initiated as quickly as possible. $^{3,6)}$

It has been shown that CBMIDA removed more plutonium from bone than either Ca-DTPA or Zn-DTPA, not only when given by intravenous injection but also when given by the oral route. ${ }^{1)}$ This effect of CBMIDA is due to its action in inhibiting bone mineralization. ${ }^{19)}$ Although the reduction of plutonium in the liver brought about by CBMIDA was less than that of Zn-DTPA in this experiment, we found no differences in plutonium content in the liver in our previous study, when CBMIDA and Zn-DTPA were given by intravenous injection. ${ }^{1)}$ Zn-DTPA was more effective in removing plutonium from kidney, spleen, and testis than CBMIDA, in the present study; however, these differences were not unknown. In any event, as our findings indicate that CBMIDA is more effective for removing plutonium from bone and that Zn-DTPA is more effective in the liver, by both oral and intravenous administration, we could anticipate that a combination of CBMIDA and Zn-DTPA would effectively remove more plutonium from the body than either agent alone.

Although no unusual findings were seen with the high dose of CBMIDA, and only slight congestion of the small intestine was seen in the $\mathrm{Zn}$ DTPA groups, further studies will be necessary to clarify the toxicity of these agents, since a dose of $1,200 \mu \mathrm{mol} / \mathrm{kg}$ exceeds the recommended dose, for example, the daily dose of DTPA for humans is $30 \mu \mathrm{mol} / \mathrm{kg}$. 


\section{CONCLUSION}

It was confirmed that CBMIDA, given orally, effectively removed plutonium from the body, being particularly effective in bone, compared with $\mathrm{Zn}$-DTPA, similar to the findings with intravenous injections. It would appear worthy to carry out clinical testing of CBMIDA for chelation therapy in persons contaminated with plutonium.

\section{REFERENCES}

1) S. Fukuda, H. Iida, Y. Hseih and W. Chen; Effect of CBMIDA [Catechol-3,6-bis(methyleiminodiacetic acid)] on removal of plutonium in rats, J. Jpn. Health Phys. Soc., 27, 11 (1992).

2) S. Fukuda, Y. Hseih and W. Chen; Toxicological study of DTPA as drug (V) Toxicities of Ca-DTPA, Ca-EDTA and CBMIDA after intravenous injection in beagle dogs, J. Jpn. Health Phys. Soc., 25, 115 (1990).

3) G.N. Stradling, S.A. Gray, M. Ellender, M. Pearce, I. Wilson, J.G. Moody and A. Hodgson; Removal of inhaled plutonium and americium from the rat by administration of ZnDTPA in drinking water, Human \& Exp. Toxicol.. 12, 233 (1993).

4) R.D. Lloyd, G.N. Taylor, C.W. Mays, C.W. Jones, F.W. Bruenger and D.R. Atherton; Dependency of chelation efficacy upon time after first DTPA injection, Radiat. Res., 78, 448 (1979).

5) R.A. Guilmette, E.S. Moretti and A. LindenBAUM; Toward an optimal DTPA therapy for decorporation of actinides: Time-dose relationships for plutonium in the $\operatorname{dog}$. I, Radiat. Res., 78, 415 (1979).

6) M.F. Sullivan and P.S. Ruemmler; Effectiveness of DTPA therapy when administered intragastrically or intraperitoneally to remove $\mathrm{Pu}$ from adult of neonatal rats, Health Phys., 51, 641 (1986).

7) J.E. Ballou and J.L. Palotay; Oral therapy for deposited plutonium, Health Phys., 12, 895 (1966).

8) V. Volf; Effect of drinking Zn-DTPA on 238-Pu and 241-Am in rat bones, Radiat. Environ. Biophys., 23, 141 (1984).
9) D.W. BaXter and M. Sullivan; Gastrointestinal absorption and retention of plutonium chelates, Health Phys., 22, 785 (1972).

10) D.M. TAYLOR; Oral chelation treatment of injected ${ }^{241} \mathrm{Am}$ or ${ }^{239} \mathrm{Pu}$ in rats, Health Phys., 38, 147 (1980).

11) H. Foreman; The effect of diethylenetriaminepentaacetic acid (DTPA) on acceleration of excretion of actinide elements, Health Phys., 8, 735 (1962).

12) S. FuKudA and H. IIDA; Toxicological study on the safety of DTPA as a drug (III). Side effects of orally administered Zn-DTPA to beagles, J. Jpn. Health Phys. Soc., 22, 439 (1991).

13) E. Stevens, B. Rosoff, M. Weiner and $H$. SPENCER; Proceeding of the society for experimental biology and medicine, Vol. III, p. 235 (1962).

14) F. Planas-Bohne and H. Ebel; Dependence of DTPA-toxicity on the treatment schedule, Health Phys., 29, 103 (1975).

15) R.D. Lloyd, J.J. Boseman, G.N. TAylor, F.W. Bruenger, D.R. Atherton, W.S. Stevens and C.W. MAYS; Decorporation from beagles of mixture of monomeric and particulate plutonium using Ca-DTPA and Zn-DTPA: Dependence upon frequency of administration, Health Phys., 35, 217 (1978).

16) F. Planas-Bohne and J. Lohbreier; Toxicological studies on DTPA, IAEA-SR-6/1, p. 505 (1976).

17) D.M. TAYLOR and J.D. Jones; Effects of ethylendiaminetetraacetate and diethylenetriaminepentaacetate of DNA. Synthesis in kidney and intestinal mucosa of folate treated rats, Biochem. Pharmacol., 21, 3313 (1972).

18) B.S. PopPlewell; The influence of diethylenetriaminepentaacetate on the synthesis of DNA, RNA and proteins in the regenerating rat liver, Biochem. Pharmacol., 23, 901 (1974).

19) S. Fukuda, H. IIdA, Y. Hseih and W. Chen; Toxicological study of DTPA as drug (VI) Effects of intravenously injected Ca-DTPA, Ca-EDTA and CBMIDA and orally administered Zn-DTPA to bone metabolism in beagle dogs, J. Jpn. Health Phys. Soc., 26, 101 (1991). 